\title{
PENGARUH PENERAPAN METODE PEMBELAJARAN BRAINSTORMING DENGAN SOAL OPEN-ENDED PADA MATERI SEGI EMPAT
}

\author{
Ulfa Hidayati ${ }^{1}$, Lili Supardi ${ }^{2}$, Rohmah Indahwati ${ }^{3}$ \\ ${ }^{1,2,3}$ Program Studi Pendidikan Matematika, FKIP, Universitas Madura \\ Email: lilisupardi@unira.ac.id
}

\begin{abstract}
Abstrak:
Tujuan penelitian ini untuk mengetahui respon siswa terhadap metode pembelajaranbrainstormingdengansoalopen-ended danuntukmengetahuiadatidaknya pengaruh metode pembelajaran brainstorming dengan soal open-ended terhadap hasil belajar siswa. Jenis penelitian yang digunakan adalah penelitian eksperimen. Penelitian inidilakukandiSMPNegeri1Proppopadatanggal26maretsampai4april2018dikelas VII D sebanyak 25 siswa sebagai kelas eksperimen dan kelas VII C sebanyak 25 siswa sebagai kelas kontrol. Teknik pengumpulan data yang digunakan yaitu lembar angket respon siswa dan tes.Sedangkan analisis datanya menggunakan uji-t. Berdasarkan hasil analisis data dapat disimpulkan sebagai berikut: (1) respon siswa dalam mengikuti metode pembelajaran brainstorming dengan soal open ended dengan rata-ratapersentase respon siswa $\geq 60 \%$ kategori dianggap positif; (2) ada pengaruh penerapan metode pembelajaran brainstorming dengan soal open-ended terhadap hasil belajar siswa yang

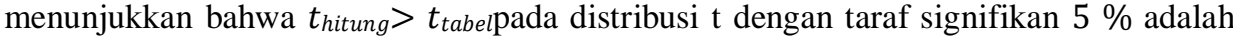
2,021 sedangkan $t_{\text {hitung }}=2,506$.
\end{abstract}

Kata Kunci: Metode Pembelajaran Brainstormingdan Soal Open-ended

\section{Pendahuluan}

Undang-undang No. 20 tahun 2003 tentang Sistem Pendidikan Nasional menyatakan bahwa Pendidikan adalah usaha sadar dan terencana untuk mewujudkan suasana belajar dan proses pembelajaran agar peserta didik secara aktif mengembangkan potensi dirinya untuk memiliki kekuatan spiritual keagamaan, pengendalian diri, kepribadian, kecerdasan, akhlak mulia, serta keterampilan yang diperlukan dirinya, masyarakat, bangsa dan negara (Sanjaya, 2009). Dengan adanya pendidikan sesorang bisa memiliki pengetahuan yang nantinya bisa diterapkan dalam kehidupan sehari-hari dan bermanfaat bagi dirinya dan orang lain. Pengetahuan yang ada harus mampu menjadi siswa berpikir kritis dalam menyelesaikan permasalahannya (Kurniati dan Zayyadi, 2018)

Kualitas sumber daya manusia dapat di kembangkan dengan proses pembelajaran. Suatu proses pembelajaran bisa terjadi saat proses belajar mengajar disekolah. Proses pembelajaran yang berlangsung hendaknya dapat meningkatkan hasil belajar siswa. Jika proses pembelajaran berjalan dengan baik maka hasil belajar siswa meningkat. Untuk memperoleh proses pembelajaran yang baik hendaknya guru dalam proses belajar mengajar menggunakan metode pembelajaran yang tepat, yaitu membuat siswa ikut berperan aktif selama proses pembelajaran.

Metode pembelajaran berperan penting dalam proses pembelajaran, karena berhasil tidaknya proses pembelajaran tergantung pada metode pembelajaran yang digunakan. Metode pembelajaran yang digunakan harus sesuai dengan tujuan pembelajaran yang diharapkan.Dalam kegiatan belajar mengajar, yang menjadi subyek yaitu siswa bukan guru. Peran guru sebagai fasilitator dan mendukung siswa selama proses pembelajaran. guru bertindak sebagai fasilitator sedangkan siswa sebagai pelaksana kegiatan belajar. Selain itu, game dapat dijadikan sebagai bentuk komunakasi dalam pembelajaran (Zayyadi, dkk, 2018).

Berdasarkan observasi yang dilakukan peneliti untuk memenuhi tugas "Problematika Matematika Sekolah" di salah satu sekolah swasta proses pembelajaran yang berlangsung masih kurang maksimal. Peran siswa masih pasif, siswa kurang aktif di dalam kelas dan 
peran guru masih dominan. Guru masih kurang memberikan kesempatan siswa untuk mengeluarkan ide-idenya, sehingga kegiatan belajar mengajar di dalam kelas masih cenderung kaku, dan siswa ketika mengerjakan soal di depan kelas masih kurang percaya diri terhadap jawaban yang mereka kerjakan. Siswa masih takutsalahdenganjawabanyangmereka

kerjakan sendiri.Oleh karena itu guru dituntut untuk memilih metode pembelajaran yang tepat sehingga peran siswa lebih aktif.

Salah satu metode pembelajaran yang dapat digunakan yaitu metode brainstorming atau yang lebih dikenal dengan metode curah pendapat. Metode brainstorming tepat digunakan dalam proses pembelajaran karena siswa dapat menyampaikan jawaban yang mereka kerjakan tanpa adanya kritik yang menghambat spontanitas penyampaian pernyataan oleh siswa dan merangsang para siswa untuk mengemukakan suatu pendapat yang terlintas dipikirannya. Suyono dan Hariyanto (2015) menyatakancurahpendapat (brainstorming) merupakan kelompok menyumbangkan sejumlah ide baru, tanpa harus dievaluasi layaktidaknya,relevan atau tidaknya ide tersebut. Dengan demikian siswa akan lebih berani dan percaya diri terhadap apa yang mereka kerjakan. Dan diharapkan dengan menggunakan metode ini dapat membantu meningkatkan keaktifan siswa dalam proses pembelajaran.

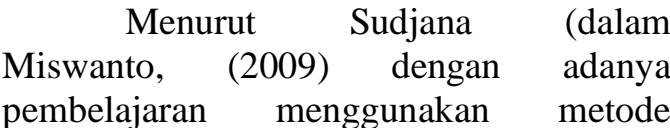
brainstorming, maka para siswa akan merasa termotivasi untuk mempelajari matematika. Dengan demikian, siswa akan lebih semangat untuk mengerjakan soalsoal matematika. Metode ini tepat digunakan dalam pembelajaran matematika, karena setiap siswa dapat menemukan ide-ide kreatif dalam penyelesaian soal-soal.

Soal-soal matematika yang banyak memancing ide-ide kreatif siswa dapat berupa soal terbuka/soal open- ended, dimana soal tersebut merupakan soal-soal yang memiliki beberapa cara atau penyelesaian yang bervariasi untuk memperoleh jawaban/solusi. Menurut Mahmudi (2008) penggunaan soal terbuka/soal open-ended juga dapat memicu tumbuhnya kemampuan berpikir kreatif.Soal open-ended memberikan kesempatan kepada siswa untuk menyelesaikan permasalahan dari berbagai sudut pandang. Dengan pemberian soalsoal open-ended memungkinkan siswa berperan aktif dalam mengembangkan metode penyelesaian masalah tanpa harus terpaku pada cara yang sudah biasa dikenalsebelumnya.

Oleh karena itu, penulis akan mengkaji sebuah metode pembelajaran brainstorming yang menitikberatkan pada pembelajaran matematika dengan soal menggunakan open-ended. Penulis memilih materi segi empat karena (1) berdasarkan wawancara yang peneliti lakukan terhadap salah satu guru SMP Negeri 1 Proppo, ditemukan banyak kesulitan dalam materi segi empat, yaitu menentukan luas dan keliling apabila soal dalam bentuk gambar atau bentuk gambar tidak sempurna; menentukan luas dan keliling apabila panjang dan lebar segi empat tersebut berupa bentuk aljabar, misalnya panjang persegi lebih besar tujuh kali lebarnya; menentukan luas dan keliling apabila soal dalam bentuk cerita; (2) banyak sekali aplikasi dari konsep segi empat yang dapat diterapkan dalam kehidupan sehari-hari;(3) dan materi segi empat merupakan materi dasar yang harus dikuasai siswa untuk memahami materi yang lebih tinggi.

Tujuan penelitian ini untuk mengetahui respon siswa terhadap metode pembelajaranbrainstormingdengansoalope n-endeddanuntukmengetahuiadatidaknya pengaruh metode pembelajaran brainstorming dengan soal open-ended terhadap hasil belajar siswa.

\section{Metode Penelitian}

Jenis penelitian ini menggunakan eksperimen yang hanya mengungkapkan hubungan sebab akibat dengan cara melibatkan kelompok kontrol disamping kelompok eksperimen. Penelitian ini dimaksudkan untuk mengetahui ada 
tidaknya pengaruh hasil belajar siswa yang diberi perlakuan dengan menggunakan metode pembelajaran brainstorming pada kelompok eksperimen dengan siswa kelompok kontrol yang tidak diberi perlakuan menggunakan metode pembelajaran brainstorming tetapi dengan model pembelajaran konvensional. Rancangan penelitian ini dapat dilihat pada Tabel 1.

Tabel 1. Rancangan Penelitian

\begin{tabular}{ccc}
\hline Kelas & Perlakuan & Postes \\
\hline $\mathrm{E}$ & $\mathrm{X}_{1}$ & $\mathrm{Y}_{1}$ \\
$\mathrm{~K}$ & $\mathrm{X}_{2}$ & $\mathrm{Y}_{2}$ \\
\hline
\end{tabular}

Keterangan :

E : Kelas eksperimen

$\mathrm{K}$ : Kelas Kontrol

$\mathrm{X} 1$ :Perlakuan dengan metode pembelajaran brainstorming

$\mathrm{X} 2$ :Perlakuan dengan model pembelajaran konvensional

Y1 : Postes ( tes hasil belajar ) kelas eksperimen

Y2 : Postes ( tes hasil belajar ) kelas kontrol

Populasi adalah keseluruhansubjek penelitian (Arikunto, 2010) Dalam penelitian ini yang dijadikan populasi adalah semua siswa kelas VII SMP Negeri 1 Proppo sebanyak 4 kelas yang berjumlah 101.Adapun populasi tersebutdiurai pada Tabel 2.

\section{Tabel 2.Data Populasi Penelitian}

\begin{tabular}{cc}
\hline Kelas & $\begin{array}{c}\text { Jumlah Peserta } \\
\text { Didik }\end{array}$ \\
\hline VII A & 26 siswa \\
VII B & 25 siswa \\
VIIC & 25 siswa \\
VIID & 25 siswa \\
\hline Jumlah & 101 siswa \\
\hline
\end{tabular}

Menurut Arikunto (2010) sampel adalah sebagian atau wakil populasi yang diteliti. Dalam penelitian ini, penentuan kelas eksperimen dan kontrol peneliti menggunakan cara acak (diundi) dimana semua anggota dalam populasi mempunyai probabilitas atau kesempatan yang sama untuk dipilih menjadi sampel.

Jadi, dari empat kelas mulai dari kelas VII A, VII B, VII C dan kelas VII D dipilih dua kelas yaitu kelas VII D sebanyak 25 siswa sebagai kelas eksperimen diajar menggunakan pembelajaran brainstorming dan VII C sebanyak 25 siswa sebagai kelas kontrol yang diajar menggunakan model pembelajaran konvensional.

Untuk memperoleh data yang diperlukan dalam suatu penelitian, maka dalam penelitian ini menggunakan teknik pengumpulan data, yaitu metode angket dan tes.Metode angket yang digunakan yaitu berupa angket tertutup, dimana siswa sudah disediakan 2 alternatif jawaban yaitu ya/tidak. Sedangkan soal tes yang diberikan harus di uji cobakan disekolah lain sebelum diberikan kepada siswa SMP Negeri 1 Proppo, untuk mengetahui layak tidaknya soal tes tersebut dengan menghitung: validitas tes, reliabilitas tes, tingkat kesukaran, dan daya beda, dengan menggunakan taraf signifikan $5 \%$. Tes tersebut di uji cobakan pada siswa SMP Negeri 1 Larangan kelas VII, dengan alasan siswa tersebut sudah mendapatkan materi segi empat dan sekolah tersebut memiliki KKM yang sama dengan sekolah SMP Negeri 1 Proppo. Dari hasil uji coba 5 soal yang diberikan semua valid dan layak untuk digunakan.

\section{Hasil dan Pembahasan \\ Hasil}

Hipotesis yang telah dirumuskan akan di uji dengan statistik parametris dengan uji-t. Sugiyono (2006) menyatakan bahwa pengaruh adanya perlakuan (treatment) dapat dianalisis dengan uji beda menggunakan statistik t- test. Sebelum pengujian hipotesis, akan dilakukan pengujian normalitas dan homogenitas dalam rangka memenuhi persyaratan uji statistik parametris uji-t. Sehingga sebelum uji-t dilakukan, terlebih dahulu mengadakan uji normalitas dan uji homogenitas. 
Tabel 3. Distribusi Frekuensi Nilai Ulangan Harian Matematika Kelas Eksperimen VII D

\begin{tabular}{cccccc}
\hline $\begin{array}{c}\text { Interval } \\
\text { kelas }\end{array}$ & $\boldsymbol{f 0}_{\mathbf{n}}$ & $\boldsymbol{f h}$ & $\boldsymbol{f 0}^{-} \boldsymbol{f} \boldsymbol{h}$ & $\begin{array}{c}\left(\boldsymbol{f 0}^{-}\right. \\
\boldsymbol{f h}^{\mathbf{2}}\end{array}$ & $\frac{\left(\boldsymbol{f}_{\mathbf{0}}-\boldsymbol{f}_{\boldsymbol{h}}\right)^{\mathbf{2}}}{\boldsymbol{f}_{\boldsymbol{h}}}$ \\
\hline $40-48$ & 2 & 0,675 & 1,325 & 1,75 & 2,59 \\
$49-57$ & 5 & 3,335 & 1,665 & 2,77 & 0,83 \\
$58-66$ & 10 & 8,49 & 1,51 & 2,28 & 0,26 \\
$67-75$ & 5 & 8,49 & $-3,49$ & 12,18 & 1,43 \\
$76-84$ & 1 & 3,335 & $-2,335$ & 5,45 & 1,63 \\
$85-93$ & 2 & 0,675 & 1,325 & 1,75 & 2,59 \\
\hline Jumlah & $\mathbf{2 5}$ & & & $\mathbf{2 6 , 1 8}$ & $\mathbf{9 , 3 3}$ \\
\hline
\end{tabular}

Berdasarkan Tabel 3 diperoleh chi kuadrat hitung $=9,33$, selanjutnya dibandingkan dengan chi kuadrat tabel dengan derajat kebebasan $(\mathrm{dk})=n-1=6$ $-1=5$, maka chikuadrat tabel $=11,070$ karena chi kuadrat hitung $\leq$ chi kuadrat tabel yaitu 9,33 $\leq 911,070$ maka distribusi data adalah normal. Jadi kelas VII D dapat dijadikan sebagai sampelpenelitian.

Tabel 4. Distribusi Frekuensi Nilai Ulangan Harian Matematika Kelas Kontrol VII C

\begin{tabular}{cccccc}
\hline $\begin{array}{c}\text { Interval } \\
\text { kelas }\end{array}$ & $\boldsymbol{f}_{\mathbf{0}}$ & $\boldsymbol{f}_{\boldsymbol{h}}$ & $\boldsymbol{f}_{\mathbf{0}}-\boldsymbol{f}_{\boldsymbol{h}}$ & $\begin{array}{c}\left(\boldsymbol{f}_{\mathbf{0}}-\right. \\
\left.\boldsymbol{f}_{\boldsymbol{h}}\right)^{\mathbf{2}}\end{array}$ & $\begin{array}{c}\left(\boldsymbol{f}_{\mathbf{0}}-\right. \\
\left.\boldsymbol{f}_{\boldsymbol{h}}\right)^{\mathbf{2}}\end{array}$ \\
\hline $40-48$ & 3 & 0,675 & 2,325 & 5,40 & 8 \\
$49-57$ & 4 & 3,335 & 0,665 & 0,442 & 0,132 \\
$58-66$ & 10 & 8,49 & 1,51 & 2,280 & 0,268 \\
$67-75$ & 6 & 8,49 & $-2,49$ & 6,2 & 0,73 \\
$76-84$ & 1 & 3,335 & $-2,335$ & 5,45 & 1,634 \\
$85-93$ & 1 & 0,675 & 0,325 & 0,105 & 0,155 \\
\hline Jumlah & $\mathbf{2 5}$ & & & $\mathbf{1 9 , 8 7 7}$ & $\mathbf{1 0 , 9 1 9}$ \\
\hline
\end{tabular}

Berdasarkan Tabel 4 diperoleh chi kuadrat hitung $=10,919$, selanjutnya dibandingkan dengan chi kuadrat tabel dengan derajat kebebasan $(\mathrm{dk})=\square-1=6$ $-1=5$, maka chi kuadrat tabel $=11,070$ karena chi kuadrat hitung $\leq$ chi kuadrat tabel yaitu $10,919 \leq 911,070$ maka distribusi data adalah normal. Jadi kelas VII C dapat dijadikan sebagai sampel penelitian. Untuk menghitung kelas itu homogen apa tidak, dapat di uraikan sebagai berikut:

Untuk kelas VII D diperoleh:

$\bar{x}=\frac{\sum f_{i} x_{i}}{\sum f_{i}}=\frac{1586}{25}=63,44$

$\mathrm{s}_{1}{ }^{2}=\frac{\sum f_{i}\left(x_{i}-\bar{x}\right)^{2}}{n-1}=\frac{3188,07}{24}=132,83$
Untuk kelas VII C diperoleh:

$\bar{x}=\frac{\sum f_{i} x_{i}}{\sum f_{i}}=\frac{1559}{25}=62,36$

$\mathrm{s}_{2}{ }^{2}=\frac{\sum f_{i}\left(x_{i}-\bar{x}\right)^{2}}{n-1}=\frac{2831,52}{24}=117,98$

Dari perhitungan diatas, besar

koefisien $\mathrm{F}$ hitung:

$F=\frac{\text { Varian terbesar }}{\text { Varian terkecil }}=\frac{132,83}{117,98}=1,12$

Harga $F$ tabel untuk tingkatkesalahan $5 \%$ adalah 1,98 dengan dkpembilang $n_{1}=25-1=24$ dan dkpenyebut $n_{2}=25-1=24$. Ternyata1,12<1,98 maka varian kelas VII C dan VII D homogen. 


\section{Pembahasan}

Tabel 5. Data Respon Siswa Kelas VII D

\begin{tabular}{|c|c|c|c|}
\hline \multirow{2}{*}{ No } & \multirow{2}{*}{ Aspek respon siswa } & \multicolumn{2}{|c|}{ Respon Siswa } \\
\hline & & & Tidak \\
\hline & $\begin{array}{l}\text { Apakah anda merasa senang mengikuti pelajaran persegi panjang dan } \\
\text { persegi? }\end{array}$ & $100 \%$ & $0 \%$ \\
\hline 2. & $\begin{array}{l}\text { Apakah anda merasa lebih mudah memahami materi persegi panjang } \\
\text { dan persegi? }\end{array}$ & $100 \%$ & $0 \%$ \\
\hline 3. & $\begin{array}{l}\text { Apakah anda merasa lebih mudah dalam memecahkan permasalahan } \\
\text { materi persegi panjang dan persegi? }\end{array}$ & $92 \%$ & $8 \%$ \\
\hline 4. & $\begin{array}{l}\text { Apakah anda menjadi lebih percaya diri dan berani dalam } \\
\text { menyampaikan pendapat? }\end{array}$ & $84 \%$ & $16 \%$ \\
\hline 5. & $\begin{array}{l}\text { Apakah anda dapat meningkatkan kerja sama yang baik dengan teman } \\
\text { kelompok? }\end{array}$ & $88 \%$ & $12 \%$ \\
\hline & Rata-rata dalam \% & $92,8 \%$ & $7,2 \%$ \\
\hline
\end{tabular}

Dari Tabel 5 diatas dapat dilihat rata-rata persentase respon siswa yang menyatakan ya terhadap metode pembelajaran brainstorming adalah $92,8 \%$ sehingga disimpulkan bahwa respon siswa dianggap positif karena apabila rata-rata persentase respon siswa $>60 \%$.

Berdasarkan hasil penghitungan, kelompok siswa yang dibelajarkan dengan metode pembelajaran brainstorming lebih tinggi dibandingkan dengan kelompok siswa yang dibelajarkan dengan pembelajaran konvensional.Tinjauan ini didasarkan pada perolehan rata-rata hasil tes dan hasil uji-t. Rata-rata hasil tes kelompok eksperimen adalah 68,12, sedangkan ratarata hasil tes yang diperoleh kelompok kontrol adalah 57,8.

\section{Simpulan dan Saran Simpulan}

Berdasarkan hasil penelitian dan pembahasan di atas maka dapat disimpulkan bahwa respon siswa dalam mengikuti metode pembelajaran brainstorming dengan soal open-ended pada materi segi empat dikelas VII SMP dengan rata-rata persentase respon siswa $\geq$ $60 \%$ dianggap positif, Saat penelitian dilakukan, selama proses pembelajaran tanggapan siswa sangat antusias untuk mengemukakan pendapatnya.

Dari hasil analisis data menunjukkan bahwa $t_{\text {hitung }}>t_{\text {tabel }}$, artinya
$H_{1}$ diterima dan $H_{0}$ ditolak. Sehingga dapat disimpulkan "Ada pengaruh penerapan metode pembelajaran brainstorming dengansoal open-ended terhadap hasil belajar siswa padamaterisegiempatdikelasVIISMP ". Dengan $t_{\text {hitung }}=2,506$ dan $t_{\text {tabel }}=$ Dengan diperoleh $t_{\text {hitung }}=2,506$, selanjutnya penuliskonsultasikan dengan $t_{\text {tabel }}$ dengan $d k=(25+25-2)=48 \quad$ diperoleh

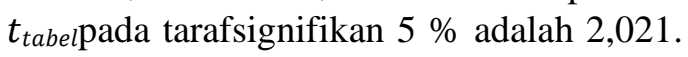
Dari nilai tersebut tampak bahwa $t_{\text {hitung }}>t_{\text {tabelyaitu }} 2,506>2,021$. Hal ini berarti bahwa $H_{1}$ diterima dan $H_{0}$ ditolak. Sehingga dapat disimpulkan " Ada pengaruh penerapan metode pembelajaran brainstorming dengansoal open-ended terhadap hasil belajar siswa padamaterisegiempatdikelasVIISMP ". Besar pengaruh metode pembelajaran brainstorming dapat dilihat dari rata-rata nilai siswa sebelum metode brainstorming dilakukan yaitu 60,4, sedangkan rata-rata nilai nilai siswa setelah dilakukan metode brainstorming yaitu 68,12 . Sehingga selisih nilai siswa sebelum dan sesuadah yaitu 7,72 .

\section{Saran}

Saran yang dapat disampaikan berdasarkan penelitian yang telah dilakukan adalah sebagai berikut: 1) Sebaiknya guru mendekati siswadengan cara memotivasinya sertamemberikan umpan 
untuk memancingpemikiran siswa, sehingga di dalam kelas para siswa tidak ada yang merasa malu atau takut untuk mengungkapkan hasil pemikirannya dengan percaya diri; 2) Sebaiknya guru harus sering mengingatkan aturan dalam metode pembelajaran brainstormingbahwa aturan yang sudah ditetapkan harus diterapkan, sehingga proses diskusi dapat berjalan dengan baik; 3) Berdasarkan hasil penelitian, metode brainstorming ini mampu meningkatkan hasil belajar siswa, oleh karena itu bisa digunakan oleh peneliti sebagai alternatif metode pembelajaran untuk meningkatkan hasil belajar siswa serta bisa didukung dengan teori yang lain untuk menambahreferensi.

\section{Daftar Pustaka}

Arikunto, S. 2010. Prosedur Penelitian Suatu Pendekatan Praktik (Edisi Revisi 2010).Yogyakarta : PT Rineka Cipta.

Kurniati, D. \& Zayyadi, M. 2018. The critical thinking dispositions of students around coffee plantation area in solving algebraic problem. International Journal of Engineering and Technology, 7 (2.10), 18-20.

Mahmudi A .2008. "Mengembangkan Soal Terbuka (Open-Ended Problem) dalam Pembelajaran Matematika “,
(Online):1-

11,(http://staffnew.uny.ac.id/upload/1 32240454/penelitian/Makalah+02+PI PM+2008+_Mengembangkan+Soal+ Terbuka_.pdf ) diakses 4 November 2017.

Miswanto. 2009. Penerapan Metode Curah Pendapat Brainstorming) Untuk Meningkatkan Motivasi Belajar Matematika Siswa Kelas Viil Mts AlFalah Simpang Kanan Rokan Hilir.Skripsi tidak diterbitkan. Pekan Baru: Universitas Islam Negeri Sultan Syarif Kasim Riau.

Sanjaya, W. 2009. Strategi Pembelajaran Berorientasi Standar Proses Pendidikan. Jakarta: Kencana.

Sugiyono.2006. Metode Penelitian Kuatitatif Kualitatif dan $R \& D$. Bandung: Alfabeta.

Suyono dan Hariyanto.2015. Implementasi Belajar dan Pembelajaran. Bandung:PT Remaja Rosdakarya.

Zayyadi, M., Hasanah, S. I., \& Surahmi, E. 2018. Ethnomatematics Exploration in Traditional Games As A Form Of Student'Social Interaction. JIPM (Jurnal Ilmiah Pendidikan Matematika), 6(2), 125-132. 